\title{
Strenge informasjonskrav ved synskirurgi og kosmetisk kirurgi
}

Lovgivningen stiller spesielt strenge krav til pasientinformasjon ved refraktiv øyekirurgi og kosmetiske operasjoner. Det fordrer at klinikker og kirurger etablerer svært gode informasjonsrutiner. Brudd på informasjonsplikten kan medføre erstatningsansvar for klinikk og kirurg selv når det ikke er begått feil under inngrepet. Ansvaret kan ikke plasseres hos Norsk pasientskadeerstatning.

\section{Ole André Oftebro}

ole.andre.oftebro@kluge.no

KLUGE Advokatfirma DA

Oslo

Etter pasientrettighetsloven $\S 4$-1 er medisinsk behandling som hovedregel avhengig av at pasienten avgir et frivillig samtykke. For at en pasient skal ha grunnlag for å treffe en veloverveid beslutning, er han/ hun avhengig av objektiv og relevant informasjon om behandlingen.
Når en pasient har et mer eller mindre akutt medisinsk behov, vil legens medisinske vurderinger i stor grad være styrende for pasientinformasjonen og valget av behandling. Ofte blir da spørsmålet snarere om pasienten motsetter seg behandlingen, enn om han positivt samtykker til den.

Ved refraktiv synskirurgi og estetisk plastikkirurgi (og annen elektiv medisinsk behandling) vil pasienten alltid kunne la være å gjennomgå behandlingen med helsen i behold. I slike tilfeller er det spesielt viktig at beslutningen om å la seg operere bygger på en grundig vurdering. Pasienten er derfor avhengig av relevant

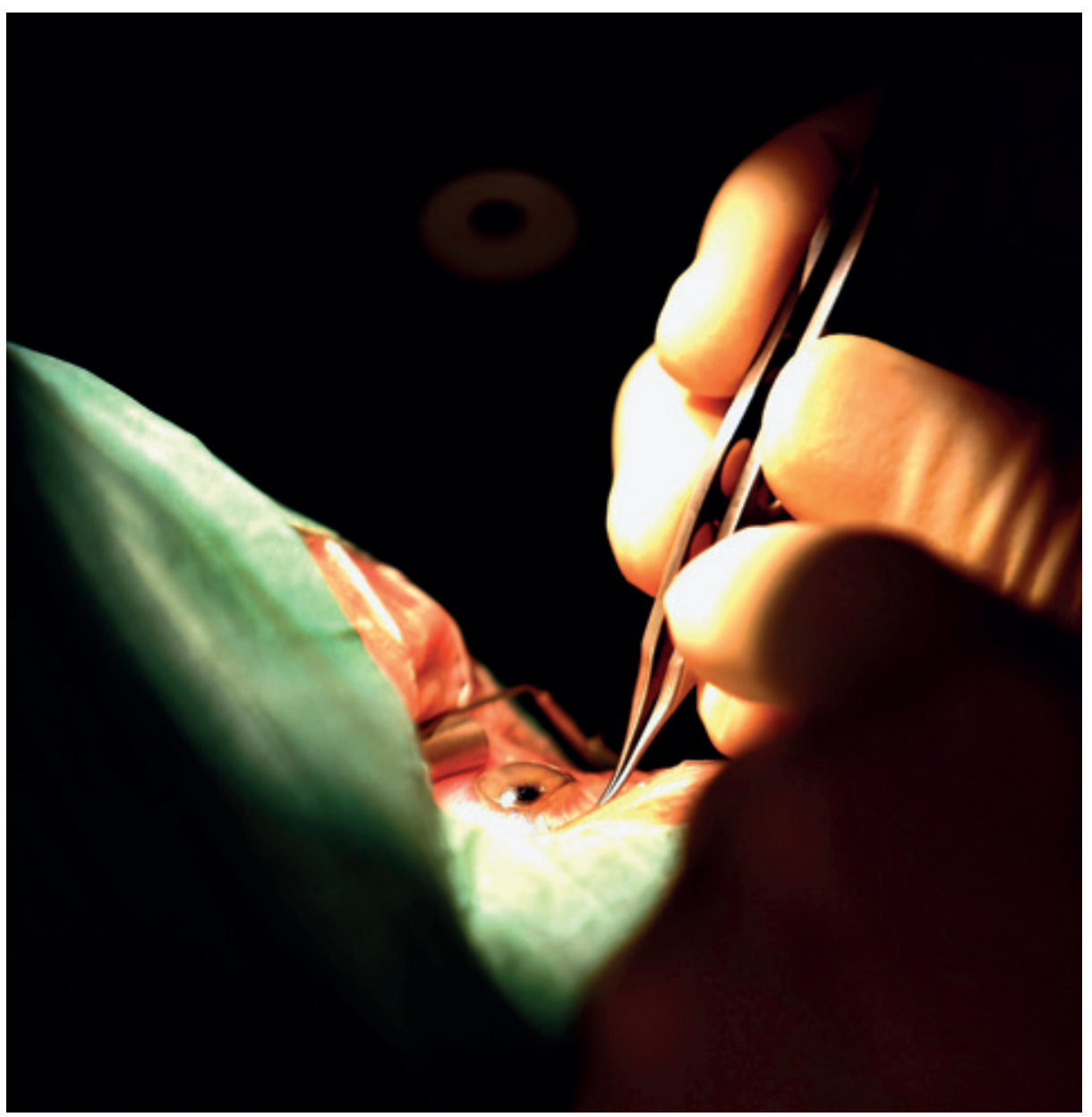

og objektiv informasjon om hvilket resultat han/hun kan vente seg, samt hvilke bivirkninger, ulemper og risikoer han/hun eventuelt utsetter seg for.

\section{Erstatningsansvar ved mangelfull eller uriktig informasjon}

Før jeg går nærmere inn på innholdet $\mathrm{i}$ informasjonsplikten, vil jeg minne om at det i seg selv kan medføre erstatningsansvar å gi mangelfull eller uriktig pasientinformasjon, selv om kirurgen ikke begår feil under selve inngrepet. Ansvaret vil kunne bli gjort gjeldende overfor både kirurg og klinikk og er ikke betinget av at det har oppstått «pasientskade» som gir rett til erstatning fra Norsk pasientskadeerstatning $(1,2)$.

En avgjørelse fra en amerikansk ankedomstol i delstaten New York egner seg godt for å illustrere dette (3). Etter en estetisk øyelokkoperasjon opplevde den kvinnelige pasienten at hun ikke kunne lukke øynene fullstendig. Hun gikk til erstatningssak, men ble ikke tilkjent erstatning $\mathrm{i}$ underinstansen. Ankedomstolen ga imidlertid kvinnen medhold og opphevet underinstansens avgjørelse. Selv om det ikke ble påvist feil ved selve utførelsen av inngrepet, var det erstatningsbetingende at kirurgen «neglected to disclose to the plaintiff (...) that at potential consequence of a blepharoplasty $(. .$.$) is a condition known as lag-$ ophtalmos whereby the eyelids fail to close compelety» (3). Med andre ord mente retten at kirurgen hadde brutt informasjonsplikten. Det er sannsynlig at informasjonssvikten ville konstituert et ansvarsgrunnlag også etter norsk rett.

\section{Innholdet i informasjonsplikten}

Det rettslige grunnlaget for informasjonsplikten i norsk lovgivning finner vi i helsepersonelloven $\S 10$ (4), som innholdsmessig korresponderer med pasientens rett til informasjon etter pasientrettighetsloven $\S \S 3-2$ og 3-5 (5).

I tillegg til helsepersonelloven $\S 10$ har generalklausulen i $\S 4$ betydning for fastleggingen av informasjonsplikten. Bestemmelsen hjemler et alminnelig forsvarlighetskrav, som omfatter alle sider av virk- 
somheten, og suppleres av de overordnede etiske prinsippene som er kommet til uttrykk i Legeforeningens etiske regler $§ 2$ (6) og Norsk plastikkirurgisk forenings regler for utøvelse av kosmetisk plastikkirurgi pkt. 1 (7). Et overordnet hensyn må være at informasjonen skal sette pasienten i stand til å vurdere hvorvidt operasjonen vil være til hans eget beste.

Både Norsk oftalmologisk forening og Norsk plastikkirurgisk forening har utformet nærmere retningslinjer for pasientinformasjon. I Kvalitetshåndboken fra Norsk oftalmologisk forening heter det, under kapitlet om refraktiv kirurgi med excimerlaser, at det skal gis «skriftlig informasjon om forventet resultat, risikoer, forholdsregler, og spesielle metodetilknyttede problemer (for eksempel nedsatt mørkesyn/haloer ved valg av liten optisk sone, risiko for haze ved større PRK-ablasjoner og lapp-problemer ved LASIK)» (8). Tilsvarende heter det i Reglene for utøvelse av kosmetisk plastikkirurgi at «pasienten må informeres grundig om inngrepet. Legen må gjøre sitt beste for å sikre at pasienten forstår informasjonen. Legen må gi en realistisk vurdering av gevinsten ved inngrepet og avdekke urealistiske forventninger» (7).

Som retningslinjene fra de fagmedisinske foreningene under Den norske legeforening viser, kan det være vanskelig å angi innholdet $\mathrm{i}$ informasjonsplikten presist. Det er imidlertid sentralt at det både må gis generell informasjon i skriftlig form og individuelt tilpasset muntlig informasjon. Etter pasientrettighetsloven $\S 3-5$ plikter kirurgen å forsikre seg om at «pasienten har forstått innholdet og betydningen av opplysningene», og det skal journalføres hvilken informasjon som er gitt (5).

Den skriftlige informasjonen bør omfatte en nærmere beskrivelse av de bivirkninger og komplikasjoner som hyppigst forekommer, samt opplysninger om alvorlige komplikasjoner som er mindre vanlig (9). Beskrivelsene må både omfatte helserisiko og risiko for at resultatet ikke blir optimalt slik som fortsatt myopi eller risiko for et estetisk lite tilfredsstillende resultat.

\section{Ole André Oftebro (f. 1981)}

er advokat i KLUGE Advokatfirma DA, Oslo. Han har vært vitenskapelig assistent ved Universitetet i Oslo og dommerfullmektig ved Øvre Romerike tingrett og har hatt en rekke oppdrag knyttet til kontrakts- og erstatningsrett, herunder pasientskadeerstatning og profesjonsansvar, både for klinikk- og pasientsiden. Ingen oppgitte interessekonflikter.
Litteratur

1. Oftebro OA. Pasientskadelov og kosmetisk kirurg - objektivt ansvar for estetiske mangler? Tidsskr Nor Lægeforen 2007: 127: 3282-3.

2. Oftebro OA. Mislighold og sanksjoner ved avtaler om kosmetisk kirurgi. Avhandling for graden cand.jur. Oslo: Det juridiske fakultet, Universitete i Oslo, 2007.

3. Karasz v Ship, New York Supreme Court, Appellate Division, First Department, Feb 11, 1992. New York: New York Supreme Court, 1992.

4. Lov om helsepersonell m.v. (helsepersonelloven). www.lovdata.no/all/nl-19990702-064.html (14.3.2011).

5. Lov om pasientrettigheter (pasientrettighetsloven). www.lovdata.no/all/hl-19990702-063.html (14.3.2011)

6. Den norske legeforening. Etiske regler for leger. www.legeforeningen.no/id/485.1 (14.3.2011).

7. Norsk plastikkirurgisk forening. Regler for utøvelse av kosmetisk plastikkirurgi. www.legeforeningen.no/id/22129.0 (14.3.2011).

8. Norsk oftalmologisk forening. Nasjonal kvalitetshåndbok for oftalmologi. www.legeforeningen.no/ id/50726.0 (14.3.2011)

9. Skene L, Smallwood R. Informed consent: lessons from Australia. BMJ 2002: 324: 39-41.

Mottatt 10.2. 2011, første revisjon innsendt 9.3. 2011, godkjent 14.4. 2011. Medisinsk redaktør Petter Gjersvik. 